\title{
Effects of Dietary Conjugated Linoleic Acid on Broiler Performance and Carcass Characteristics
}

\author{
Kátia Maria Cardinal ${ }^{1}$, Mariana Lemos de Moraes $^{1}$, Rodrigo Borille ${ }^{1}$, Gustavo Dias Lovato ${ }^{1}$, \\ Marcos Speroni Ceron ${ }^{1}$, Lucas de Marques Vilella ${ }^{1} \&$ Andréa Machado Leal Ribeiro ${ }^{1}$ \\ ${ }^{1}$ Laboratório de Ensino Zootécnico, Departamento de Zootecnia, Faculdade de Agronomia, Universidade Federal \\ do Rio Grande do Sul, Porto Alegre, Rio Grande do Sul, Brazil \\ Correspondence: Kátia Maria Cardinal, Laboratório de Ensino Zootécnico, Departamento de Zootecnia, \\ Faculdade de Agronomia, Universidade Federal do Rio Grande do Sul, Rua Bento Gonçalves, 7712, Bairro \\ Agronomia, CEP: 915400-000, Porto Alegre, Rio Grande do Sul, Brazil. Tel: 55-55-8125-4737. E-mail: \\ katia.zootecnia@hotmail.com
}

$\begin{array}{lc}\text { Received: March 2, } 2017 & \text { Accepted: March 30, } 2017 \quad \text { Online Published: April 15, } 2017 \\ \text { doi:10.5539/jas.v9n5p208 } & \text { URL: https://doi.org/10.5539/jas.v9n5p208 }\end{array}$

\begin{abstract}
The effects of three levels of conjugated linoleic acid dietary inclusion on the carcass characteristics and performance of broilers were evaluated. A total of 405 chickens were raised from 1 until 42 days of age, housed in a room with water and food ad libitum. The experimental design was completely randomized, with three treatments $(0.0,0.5$ and $1 \%$ CLA) and nine replications (pen) to performance analysis, 18 replications (two birds per pen) to carcass composition, and five replications (left legs) to lipid profile. Performance was determined weekly and after 42 days, 18 birds per treatment were slaughtered to quantify breast and leg yield. Protein and fat was quantified in the leg and breast, as well as the detailed lipid profile of the leg. Data were analyzed by ANOVA and means compared by LS means. From 1 to 21 days chickens with $0 \%$ supplementation of CLA performed better compared to those receiving 0.5 and $1 \%$ CLA $(\mathrm{P}<0.05)$, however, these differences were no longer significant from 21 to 42 days or for the overall study period $(\mathrm{P}>0.05)$. Conjugated linoleic acid inclusion did not influence leg, breast and carcass yield, and leg and breast content of protein and fat. Both levels of CLA changed the leg lipid profile: there was an increased accumulation of CLA in meat, increased levels of saturated fatty acids and reduction of polyunsaturated fatty acids. Conjugated linoleic acid supplementation increased n-6:n-3 ratio. CLA supplementation in broiler feed is effective to produce meat enriched with its isomers and change lipid profile.
\end{abstract}

Keywords: broiler, fatty acid, functional food, meat quality, performance

\section{Introduction}

Conjugated linoleic acid (CLA) is a polyunsaturated fatty acid and represents a mixture of positional and geometric isomers with conjugated double bonds of octadecadienoic acid (C18: 2) (Gouvêa, Franco, Marques, \& Pereira Netto, 2012) and was originally isolated from beef extracts (Pariza \& Hargraves, 1985). It has subsequentaly become the subject of research, particularly when CLA was topically applied to the dorsal skin of mice and tumor incidence was lowered by about 50\% compared with control mice (Ha, Grimm, \& Pariza, 1987). Among the several isomers of CLA, emphasis has been given to cis- 9 , trans-11 and trans-10, cis-12 due to the beneficial biological effects identified and associated with them (Kennedy et al., 2010). CLA has an effect in reducing fat and increasing lean mass in humans (Chen et al., 2012) and studies in animal models have confirmed that CLA has anticarcinogenic effects and can act at various stages of development of cancer (Padilha \& Pinheiro, 2004). CLA is a modulator of PPAR alpha (Miranda et al., 2011) and PPAR gamma (Yuan, Chen, \& $\mathrm{Li}, 2015)$, whereas the PPAR gamma induces apoptosis of cancer cells and inhibits the proliferation of prostate, breast and colon cancer in humans (Mueller et al., 2000; Sarraf et al., 1999; Tontonoz \& Spiegelman, 2008). When studied separately, the CLA isomers presented different effects. Trans-10, cis-12 isomer is involved in the reduction of body fat, whereas cis-9, trans-11 isomer did not show the same effect (Wang \& Jones, 2004). In another research, Lavillonniere et al. (2003) supplementing 1\% CLA in the rats diets, observed that only the trans-10, cis-12 isomer increased the number of adenomas in colon tumors. Broilers are highly sensitive to changes in the level and type of lipid in the diet, thus it is possible to incorporate CLA isomers in commercial 
breeds (Suksombat, Boonmee, \& Lounglawan, 2007). When supplemented in broiler diets, CLA influences the elongation and desaturation of various fatty acids, modifying the ratio among them (Javadi et al., 2007; Buccioni et al., 2009; Halle, Jahreis, Henning, Kohler, \& Danicke, 2012). CLA influenced feed intake, weight gain and feed conversion of broilers, and demonstrated ability to alter the amount of fat and protein and carcass yield (Suksombat, Boonmee, \& Lounglawan, 2007; Zhang et al., 2008; Halle, Jahreis, Henning, Kohler, \& Danicke, 2012; Jiang, Nie, Qu, Bi, \& Shan, 2014; Moraes, Ribeiro, Santin, \& Klasing, 2015). The results demonstrated by previous studies have shown that the CLA results depend on the supplemental dose, but it is still unclear which dosage has a positive effect on the productive variables and carcass characteristics. Consumers are increasingly interested in functional foods with nutritional characteristics that can provide beneficial substances to health, so it is interesting to enrich chicken meat with CLA, while maintaining the production levels. Therefore, the aim of this study was to evaluate the effect of dietary supplementation of CLA at different levels on broiler performance, carcass yield and lipid composition in the main commercialized cuts.

\section{Method}

\subsection{The Material Studied}

The experiment consisted of three treatments arranged as a dose-response method, with either $0.0,0.5$ and $1 \%$ dietary inclusion of conjugated linoleic acid (CLA). The oil rich in CLA was obtained from BASF S/A, São Paulo, Brazil, and consisted of $50 \%$ of cis-9, trans-11 and 50\% of 10-trans, 12-cis CLA isomers, which is produced from alkaline isomerization of oils rich in linoleic acid.

\subsection{Area Descriptions}

The broilers were housed in a building with 27 pens of $1 \mathrm{~m}^{2}$ with wood shavings, equipped with two nipples drinker and one tubular feeder. Environmental temperatures were managed with heaters to maintain birds in thermoneutral conditions during the experimental period.

\subsection{Methodology}

All procedures used in this experiment were approved by the Ethics Committee on Animal Use of Federal University of Rio Grande do Sul, under protocol number 20669 and follow the legislation for the protection of animals used for scientific purposes. A total of 405 Cobb 500 male broiler chickens $( \pm 40 \mathrm{~g})$ were used, which were obtained directly from the hatchery (Languiru, Teutonia city, Rio Grande do Sul, Brazil). On the first day of life, 15 bird groups were weighed and distributed in pens, ensuring the variation in weight among groups of birds did not exceed 3\%. At 35 days, the capacity was adjusted to 10 animals per pen and birds were reared until 42 days. Each pen represented an experimental unit. The feed supply and water were ad libitum, and the animals were kept in thermal confort.

A three phase feeding program was used-starter (1 to 7 days), grower ( 8 to 21 days) and finisher (22-42 days) - formulated with nutritional levels recommended by the Poultry and Swine Brazilian Tables (Rostagno et al., 2011), differing only in the addition levels of CLA isomers, replacing soybean oil (Table 1). 
Table 1. Ingredient formulas and chemical composition of experimental diets fed to broilers receiving different inclusion levels $(0.0,0.5$ or $1.0 \%)$ of conjugated linoleic acid as-fed basis

\begin{tabular}{|c|c|c|c|}
\hline Item & Initial & Growth & Finish \\
\hline \multicolumn{4}{|l|}{ Ingredients, \% } \\
\hline Corn & 53.80 & 53.94 & 61.99 \\
\hline Soybean Meal, $45 \%$ Crude Protein & 39.33 & 38.53 & 30.47 \\
\hline Vegetal Oil $^{1}$ & 2.53 & 3.83 & 4.17 \\
\hline Dicalcium Phosphate & 1.90 & 1.56 & 1.25 \\
\hline Limestone & 1.00 & 1.00 & 0.88 \\
\hline Salt & 0.51 & 0.48 & 0.46 \\
\hline L-Lys $\mathrm{HCl}$ & 0.27 & 0.16 & 0.25 \\
\hline DL-Met & 0.36 & 0.29 & 0.28 \\
\hline L-Tre & 0.10 & 0.04 & 0.07 \\
\hline Mineral Premix ${ }^{2}$ & 0.10 & 0.08 & 0.08 \\
\hline Vitaminic Premix ${ }^{2}$ & 0.05 & 0.04 & 0.04 \\
\hline Choline Chloride $60 \%$ & 0.05 & 0.05 & 0.05 \\
\hline \multicolumn{4}{|l|}{ Nutricional Values (calculated) } \\
\hline $\mathrm{ME}, \mathrm{Mcal} / \mathrm{kg}$ & 2.96 & 3.05 & 3.17 \\
\hline Crude Protein, \% & 22.55 & 22.01 & 19.10 \\
\hline Crude Fiber, \% & 3.02 & 2.98 & 2.69 \\
\hline Fat, \% & 5.15 & 6.43 & 6.94 \\
\hline Dry Matter, \% & 87.56 & 87.85 & 87.66 \\
\hline \multicolumn{4}{|l|}{ Nutricional Values (calculated), \% } \\
\hline Lys dig. & 1.32 & 1.22 & 1.10 \\
\hline Met dig. & 0.65 & 0.58 & 0.54 \\
\hline Met + Cys dig. & 0.95 & 0.88 & 0.80 \\
\hline
\end{tabular}

Note. ${ }^{1}$ In diets containing $0 \%$ CLA all vegetable oil used was soybean oil. Treatment with $0.5 \%$ CLA, used $0.83 \%$ CLA and $0.87,3.0$ and $3.34 \%$ of soybean oil for starting, grower and finisher diets, respectively. Treatment with $1 \%$ CLA, used $1.67 \%$ CLA and $0.86,2.16$ and $2.5 \%$ of soybean oil for starting, grower and finisher diets, respectively.

${ }^{2}$ Composition (content per kg of premix): $150000 \mathrm{mg}$ of Mn, $100000 \mathrm{mg}$ of $\mathrm{Zn}, 80000 \mathrm{mg}$ of Fe, $15000 \mathrm{mg}$ of $\mathrm{Cu}, 1200 \mathrm{mg}$ of I, $700 \mathrm{mg}$ of Se, $23200000 \mathrm{UI}$ of A vitamin, $5600000 \mathrm{UI}$ of D vitamin, $52000 \mathrm{mg}$ of K vitamin, $6000 \mathrm{mg}$ of B1vitamin, $18000 \mathrm{mg}$ of B2vitamin, $9000 \mathrm{mg}$ of B6vitamin, $132000 \mathrm{mg}$ of niacin, $44000 \mathrm{mg}$ of panthotenic acid, $2400 \mathrm{mg}$ of folic, $200000 \mu \mathrm{g}$ of biotin, $40000 \mu \mathrm{g}$ of B12 vitamin.

Body weight (BW), feed intake (FI), weight gain (WG) and feed conversion (FC) were measured weekly to evaluate growth performance. At 42 days of age, 18 birds per treatment ( 2 birds per pen) were slaughtered to evaluate legs fat and protein content and carcass, breast and leg (thigh + drumstick) yield. Animals were slaughtered by cervical dislocation and subsequent bleeding. Birds went through scalding, plucking of the feathers and evisceration. Carcasses were weighed without head, feet and viscera and sectioned in commercial cuts by a competent person; legs and breast were weighed to calculate the yield of each cut, and the legs were designated for nutritional composition analysis. Analysis of dry matter (method number 930.15), ash (method number 923.03), crude protein (method number 976.05) and gross energy (isoperibolic calorimetric bomb model C2000 - IKA Werke GmbH \& Co. KG, Staufen, Germany) were conducted under the rules of AOAC (1996). The crude fat (CF) was calculated using the formula:

$$
\mathrm{CF}=[\text { Crude Energy }-(\text { Crude Protein } \times 56.6)] / 94
$$

Fatty acid profile analyses of the leg were made in five samples per treatment, each one with a total of $50 \mathrm{~g}$ of thigh and drumstick sub-samples. The total lipid extraction and quantification was made according the technique proposed by Hara et al. (1978) using isopropanol, while the esterification was made by methanolic boron trifluoride. Fatty acids quantification was measured according to Christie (1989). The fatty acid profile was determined using a gas chromatograph (Agilent 45813-01, USA), equipped with an ionization detector (FID) and a capillary column of fused silica $100 \mathrm{~m}$ length $\times 250 \mu \mathrm{m}$ diameter (Supelco 2560). Nitrogen was used as carrier gas with a flow of $1 \mathrm{~mL}$ per min and sample injection volume of $1 \mathrm{uL}$ in 1/50 split mode, with injection and detection temperature of $250{ }^{\circ} \mathrm{C}$. The fatty acids were identified by comparison between standards of known 
methyl esters retention time (Sigma: Supelco Mix 37 Components FAME; Linoleic Acid Methyl Ester Mix (cis/trans), trans-11-Octadecenoic Methyl Ester; Linoleic Acid Conjugated methyl Ester), and the samples esterified.

The experimental design was completely randomized, with three levels of dietary inclusion of CLA oil (0.0, 0.5 and $1 \% \mathrm{CLA}$ ) and nine replications (pen) to performance analysis were used. Eighteen replications (two birds per pen) were used to obtain legs nutritional composition and carcass, breast and leg yield, and five left legs per treatment were used to analyse lipid profile. All responses were analyzed by ANOVA and in the presence of a significant $\mathrm{F}$, the means were compared by LSmeans by SAS statistical program $(\mathrm{P}<0.05)$.

\section{Results}

\subsection{Growth Performance and Body Composition}

The chickens supplemented with 0\% CLA obtained better body weight (BW), weight gain (WG) and feed conversion (FC) than the chickens fed 0.5 and $1 \%$ of CLA during the $1-21$ days old (d) period $(\mathrm{P}<0.05)$. However, differences on WG and FC observed in the initial period were not maintained during 22-42 d, nor in the 1-42 d period (Table 2).

Table 2. Effect of different dietary levels of conjugated linoleic acid (CLA) on broiler performance reared from1 to 42 days of age

\begin{tabular}{|c|c|c|c|c|c|}
\hline \multirow{2}{*}{ Variable } & \multicolumn{3}{|c|}{ CLA Levels } & \multirow{2}{*}{ SEM } & \multirow{2}{*}{$\mathrm{P}$} \\
\hline & $0 \%$ & $0.5 \%$ & $1 \%$ & & \\
\hline \multicolumn{6}{|l|}{$1-21 d$} \\
\hline Live Weight 21 (g) & $920^{\mathrm{a}}$ & $897^{\mathrm{ab}}$ & $873^{b}$ & 10 & 0.010 \\
\hline Feed Intake (g) & 1145 & 1121 & 1150 & 15 & 0.376 \\
\hline Weight Gain (g) & $874^{\mathrm{a}}$ & $856^{\mathrm{ab}}$ & $833^{b}$ & 11 & 0.033 \\
\hline Feed Conversion & $1.30^{\mathrm{a}}$ & $1.31^{\mathrm{b}}$ & $1.38^{\mathrm{b}}$ & 0.02 & 0.030 \\
\hline \multicolumn{6}{|l|}{$22-42 d$} \\
\hline Live Weight 42 (g) & 2763 & 2694 & 2687 & 34 & 0.251 \\
\hline Feed Intake $(\mathrm{g})$ & 3036 & 2916 & 2820 & 73 & 0.147 \\
\hline Weight Gain (g) & 1844 & 1791 & 1831 & 25 & 0.311 \\
\hline Feed Conversion & 1.64 & 1.62 & 1.54 & 0.04 & 0.108 \\
\hline \multicolumn{6}{|l|}{$1-42 d$} \\
\hline Live Weight 42 (g) & 2763 & 2694 & 2687 & 34 & 0.251 \\
\hline Feed Intake (g) & 4182 & 4023 & 4078 & 44 & 0.058 \\
\hline Weight Gain (g) & 2715 & 2636 & 2669 & 25 & 0.102 \\
\hline Feed Conversion & 1.54 & 1.53 & 1.53 & 0.01 & 0.729 \\
\hline
\end{tabular}

Note. ${ }^{\mathrm{a}, \mathrm{b}}$ Means followed by different letters in the same row are different $(\mathrm{P}<0.05)$.

There was no effect of different CLA levels on carcass, breast and leg yield and the amount of protein and fat in the leg and breast $(\mathrm{P}>0.05)$ (Table 3).

Table 3. Effect of different dietary levels of conjugated linoleic acid (CLA) on carcass yield and composition of comercial cuts at 42 days of age

\begin{tabular}{|c|c|c|c|c|c|}
\hline \multirow{2}{*}{ Item } & \multicolumn{3}{|c|}{ CLA, $\%$} & \multirow{2}{*}{ SEM } & \multirow{2}{*}{$P$} \\
\hline & 0 & 0.5 & 1 & & \\
\hline \multicolumn{6}{|l|}{ Yield, \% } \\
\hline Carcass & 77.0 & 76.4 & 77.5 & 0.2 & 0.112 \\
\hline Breast & 37.2 & 36.6 & 37.4 & 0.4 & 0.414 \\
\hline $\operatorname{Leg}^{1}$ & 31.1 & 30.8 & 30.6 & 0.3 & 0.537 \\
\hline \multicolumn{6}{|c|}{ Leg composition ${ }^{2}, \%$} \\
\hline Crude Fat & 29.8 & 28.6 & 29.7 & 0.9 & 0.531 \\
\hline Crude Protein & 65.4 & 66.9 & 65.6 & 1.0 & 0.368 \\
\hline
\end{tabular}

Note. ${ }^{1}$ Leg $=$ thigh + drumstick; ${ }^{2}$ Leg composition on Dry Matter. 


\subsection{Fatty Acid Profile}

The profile of chicken leg fatty acids was changed significantly $(\mathrm{P}<0.05)$ by the dietary inclusion of CLA (Table 4). As expected, incorporation of CLA in tissues increased according to increased levels of supplementation, chickens supplemented with $0.5 \%$ and $1.0 \%$ CLA had deposition 54.77 and $63.47 \%$ higher than the treatment without supplementation $(\mathrm{P}<0.05)$. The cis-9, trans-11 isomer was found in greater extent, representing approximately $60 \%$ of total CLA, $20 \%$ more uptake than the isomer trans-10, cis- 12 , in both supplementation levels. When CLA was supplemented, there was an increase in the level of saturated fatty acids (SFA) myristic, palmitic, stearic and arachidic, and reduction of polyunsaturated fatty acids (PUFA) linoleic, alpha-linoleic, and at level of $1 \%$ supplementation, arachidonic, DPA and DHA were reduced. There was a decrease of 32.4 and $35.9 \%(\mathrm{P}<0.05)$ in ratio PUFA:SFA when broilers received 0.5 and $1.0 \%$ of CLA. The changes in PUFA levels increased $(\mathrm{P}<0.05)$ the $\mathrm{n}-6: \mathrm{n}-3$ ratio, broiler supplemented with $0.5 \%$ and $1.0 \%$ CLA had ratio 7.57 and $18.09 \%$ higher than the treatment without CLA supplementation.

Table 4. Effect of different dietary levels of conjugated linolenic acid (CLA) on the leg ${ }^{1}$ fatty acid profile of broiler at 42 days of age

\begin{tabular}{|c|c|c|c|c|c|}
\hline \multirow{2}{*}{ Fatty Acid, g/100 g FAME ${ }^{2}$} & \multicolumn{3}{|c|}{ CLA inclusion, $\%$} & \multirow{2}{*}{$S E M$} & \multirow{2}{*}{$P$} \\
\hline & 0 & 0.5 & 1 & & \\
\hline \multicolumn{6}{|l|}{ Saturated } \\
\hline $\mathrm{C} 12: 0$ & 0.07 & 0.09 & 0.08 & 0.12 & 0.673 \\
\hline $\mathrm{C} 14: 0$ & $0.54^{\mathrm{b}}$ & $0.80^{\mathrm{a}}$ & $0.86^{\mathrm{a}}$ & 0.04 & 0.000 \\
\hline C15:0 & 0.08 & 0.09 & 0.09 & 0.00 & 0.069 \\
\hline $\mathrm{C} 16: 0$ & $20.31^{\mathrm{b}}$ & $24.31^{\mathrm{a}}$ & $25.24^{\mathrm{a}}$ & 0.44 & 0.000 \\
\hline $\mathrm{C} 17: 0$ & 0.16 & 0.20 & 0.27 & 0.03 & 0.081 \\
\hline C18:0 & $8.29^{b}$ & $12.28^{\mathrm{a}}$ & $12.71^{\mathrm{a}}$ & 0.23 & 0.000 \\
\hline $\mathrm{C} 20: 0$ & $0.07^{\mathrm{b}}$ & $0.09^{\mathrm{a}}$ & $0.10^{\mathrm{a}}$ & 0.00 & 0.000 \\
\hline \multicolumn{6}{|l|}{ Monounsaturated } \\
\hline $\mathrm{C} 14: 1$ & 0.09 & 0.07 & 0.11 & 0.03 & 0.505 \\
\hline C16:1 & $2.97^{\mathrm{a}}$ & $1.67^{\mathrm{b}}$ & $1.22^{\mathrm{b}}$ & 0.15 & 0.000 \\
\hline C18:1 trans- 9 & $0.13^{b}$ & $0.18^{\mathrm{a}}$ & $0.17^{\mathrm{a}}$ & 0.01 & 0.001 \\
\hline C18:1 trans-11 & $0.06^{\mathrm{c}}$ & $0.24^{\mathrm{b}}$ & $0.35^{\mathrm{a}}$ & 0.02 & 0.000 \\
\hline $\mathrm{C} 18: 1$ & $27.57^{\mathrm{a}}$ & $21.09^{\mathrm{b}}$ & $20.21^{\mathrm{b}}$ & 0.53 & 0.000 \\
\hline $\mathrm{C} 20: 1$ & $0.31^{\mathrm{a}}$ & $0.26^{\mathrm{b}}$ & $0.24^{\mathrm{b}}$ & 0.01 & 0.000 \\
\hline \multicolumn{6}{|l|}{ Polyunsaturated } \\
\hline $\mathrm{C} 18: 2$ & $30.92^{\mathrm{a}}$ & $28.26^{\mathrm{b}}$ & $27.07^{\mathrm{b}}$ & 0.56 & 0.001 \\
\hline C18:3 n-6 & 0.20 & 0.20 & 0.18 & 0.02 & 0.697 \\
\hline C18:3n-3 & $2.31^{\mathrm{a}}$ & $1.82^{\mathrm{b}}$ & $1.80^{\mathrm{b}}$ & 0.07 & 0.000 \\
\hline C18:2 cis- 9 trans- 11, CLA & $0.11^{\mathrm{c}}$ & $1.77^{\mathrm{b}}$ & $3.75^{\mathrm{a}}$ & 0.11 & 0.000 \\
\hline C18:2 trans-10 cis- 12 , CLA & $0.07^{\mathrm{c}}$ & $1.07^{\mathrm{b}}$ & $2.28^{\mathrm{a}}$ & 0.07 & 0.000 \\
\hline $\mathrm{C} 20: 2$ & $0.46^{\mathrm{ab}}$ & $0.53^{\mathrm{a}}$ & $0.36^{\mathrm{b}}$ & 0.04 & 0.032 \\
\hline$C 20: 3 n-6$ & $0.56^{\mathrm{a}}$ & $0.48^{\mathrm{a}}$ & $0.26^{\mathrm{b}}$ & 0.04 & 0.000 \\
\hline $\mathrm{C} 20: 3 \mathrm{n}-3$ & 0.06 & 0.12 & 0.05 & 0.04 & 0.332 \\
\hline $\mathrm{C} 20: 4$ & $3.37^{\mathrm{a}}$ & $3.05^{\mathrm{a}}$ & $1.76^{\mathrm{b}}$ & 0.24 & 0.001 \\
\hline $\mathrm{C} 20: 5$ & 0.13 & 0.19 & 0.14 & 0.02 & 0.221 \\
\hline $\mathrm{C} 22: 5$ & $0.63^{\mathrm{a}}$ & $0.71^{\mathrm{a}}$ & $0.41^{\mathrm{b}}$ & 0.06 & 0.006 \\
\hline $\mathrm{C} 22: 6$ & $0.44^{\mathrm{a}}$ & $0.37^{\mathrm{a}}$ & $0.20^{\mathrm{b}}$ & 0.04 & 0.001 \\
\hline \multicolumn{6}{|l|}{ Fatty acids ratio } \\
\hline$n-6: n-3$ & $9.65^{\mathrm{c}}$ & $10.44^{\mathrm{b}}$ & $11.78^{\mathrm{a}}$ & 0.06 & 0.001 \\
\hline PUFA:SFA & $1.42^{\mathrm{a}}$ & $0.96^{\mathrm{b}}$ & $0.91^{\mathrm{b}}$ & 0.19 & 0.001 \\
\hline
\end{tabular}

Note. ${ }^{\text {a, }}$ Means followed by different letters in the same row are different $(\mathrm{P}<0.05) .{ }^{1}$ Leg $=$ thigh + drumstick; ${ }^{2}$ FAME $=$ Fatty Acid Methyl Ester. 


\section{Discussion}

\subsection{Growth Performance and Body Composition}

Previous studies observed similar effect on performance over the total rearing period when broilers were also supplemented up to $1 \%$ CLA (Zhang, Guo, Tian, \& Yuan, 2008; Halle, Jahreis, Henning, Kohler, \& Danicke, 2012; Jiang, Nie, Qu, Bi, \& Shan, 2014). However, Suksombat, Boonmee, and Lounglawan (2007) supplemented the broilers diets from 21 to $42 \mathrm{~d}$ with up to $1.5 \%$ CLA and observed approximately $12 \%$ less average daily gain when compared to 1\% CLA supplementation. In the present study, CLA exerted a negative effect on weight gain and feed conversion in the initial rearing period (1-21 d). Moraes, Ribeiro, Santin, Klasing (2015) found similar results when broilers were fed diets containing 1 and 2\% CLA. West et al. (1998) observed a performance reduction in mice fed CLA and attributed this result to increased energy expenditure, suggesting increase in energy demand for maintenance. The mechanism by which CLA affects energy metabolism is still unknown, but some studies suggest that it is by increasing oxygen consumption (Choi et al., 2004) and increased expression of uncoupling proteins (Park \& Song, 2004). According to Moraes, Ribeiro, Santin, and Klasing (2015) if broiler performance is altered by changes in adipose tissue, CLA should have a greater impact on performance at the end of rearing period (22-42 d) when there is greater deposition of fat, and not in the initial phase (1-22 d), when protein deposition rates are higher. Kang, Liu, Albright, Park, and Pariza (2003) reported that trans-10, cis-12 isomer inhibits the differentiation of 3T3-L1 adipocytes and decreases the receptor activated by peroxisome proliferator gamma expression, suggesting that fat reduction can be linked in part to the inhibition of pre-adipocyte differentiation (Zhou, Sun, Liu, \& Zhao, 2008; Yuan, Chen, \& Li, 2015). Due to the complex metabolism of CLA, more studies are necessary to define its association with loss of performance in broiler starter phase.

Suksombat, Boonmee, and Lounglawan (2007), supplementing broilers with up to $1.0 \%$ CLA, observed no differences in yield or in the amount of protein and fat in breast, thighs and drumsticks. But when 1.5\% CLA was supplemented, there was a reduction of fat amount in the thigh. Such benefit may be associated to CLA reducing body fat by decreasing adipose cell mass or cell number. This can be achieved in part by increasing lipoprotein lipase at adipose cells, enhancing apoptosis of preadipocytes and adipocytes, and modulating lipolysis (Hargrave et al., 2004, Storkson, Park, Cook, \& Pariza, 2005). Contrarily to our findings, Szymczyk, Pisulewski, Szczurek, and Hanczakowski (2001) observed an increase in leg yield and reduction of abdominal fat content when the level of CLA supplementation was 1\%. In contrast, Duh and Ahn (2002) fed broilers with $0.5 \%$ CLA during 3 weeks from 21 days old and observed an increase in abdominal fat content. The differences in the results found in these studies may be related to differences in diet ingredients, supplementation period, age and strain of the birds (Pariza, Park, \& Cook 2001; Suksombat, Boonmee, \& Lounglawan, 2007). Another important factors are the isomers used and the ratio between them, because studies show that isomers have different results on performance. The trans-10, cis-12 isomer has been associated with a fat reduction effect, while the cis- 9 , trans-11 isomer has been reported to have no effect (Wang \& Jones, 2004; Martorell, 2012).

\subsection{Fatty Acid Profile}

Broilers are highly sensitive to changes in the level and type of lipid in the diet, so was expected changes in fatty acid profile. The incorporation of CLA in tissues increased according to increased levels of supplementation, demonstrating that dietary CLA were efficient transferred. But the concentration of individual CLA isomers in muscle does not reflect those in the diet, the cis-9, trans- 11 isomer was found in greater extent, $20 \%$ more uptake than the isomer trans-10, cis-12, in both supplementation levels, and the percentage of cis-9, trans-11 and trans-10, cis- 12 in the CLA source were 50 and $50 \%$. Similar results were found by Suksombat, Boonmee, and Lounglawan (2007) and Buccioni et al. (2009). It is not fully understood why this isomer is incorporated in greater quantity. However, it may be connected to the fact that some isomers have better mobilization efficiency than others (Zang et al., 2007), and has a preference for deposition.

Conjugated linoleic acid has the capacity to interfere in lipid metabolism, using the oleic acid metabolic pathway to accumulate in the tissues, or metabolize in the same pathway of linoleic acid by influencing the desaturation and elongation of other fatty acids (Carta et al., 2002). When CLA was supplemented, there was an increase in the level of SFA and reduction of PUFA. The reduction of arachidonic acid, DHA, EPA and its precursor, alpha-linoleic and linoleic acids, may have occurred because CLA also competes by the enzyme $\Delta 6$ desaturase (Duarte et al., 2010). The linoleic acid reduction was likely associated with the substitution of soybean oil, which contains $55 \%$ of this fatty acid (Smith et al., 2006). The increasing levels of SFA and reduction of other PUFA is linked to the inhibition of the enzyme $\Delta 9$ desaturase in the liver, caused by greater levels of CLA (Suksombat, Boonmee, \& Lounglawan, 2007) and impaired conversion of stearic acid to oleic acid by reduction of the 
enzyme stearoyl-CoA desaturase in the liver. As result of these changes there was a decrease $(\mathrm{P}<0.05)$ in ratio PUFA:SFA: $1.42 ; 0.96$ and 0.91 to $0.0 ; 0.5$ and $1.0 \%$ CLA. Although there was a reduction of this relationship, it is kept above 0.45, recommended as beneficial by the Brazilian Society of Cardiology (Santos et al., 2013). The changes in PUFA levels increased $(\mathrm{P}<0.05)$ the $\mathrm{n}-6: \mathrm{n}-3$ ratio: $9.65 ; 10.44$ and 11.78 to $0.0 ; 0.5$ and $1.0 \%$ CLA. Food and Agriculture Organization of the United Nations (2010) considered beneficial n-6:n-3 ratios in the range of 4.0 to 5.0. High intake of SFA coupled with low intake of MUFA, together with a low n-6:n-3 ratio in human diet has been linked to the production of thromboxanes, leukotrienes and $\mathrm{C}$-reactive protein, which are related to various diseases such as diabetes, cancer, obesity, rheumatoid arthritis and asthma (Simopoulos, 2004). Enrichment of chicken meat with CLA must be analyzed not only for the beneficial effects of CLA per se, but also by changes in profile of other fatty acids.

\section{Conclusions}

Dietary CLA supplementation at 0.5 and $1.0 \%$ levels did not exert a negative effect on growth performance in the total period of broiler rearing, yield of relevant cuts of meat and their nutritional composition, but decreased performance in the initial growth period.

Conjugated linolenic acid inclusion in poultry diet is an effective way to produce meat enriched with its isomers. CLA also reduced PUFA content and increase n-6:n-3 ratio in leg meat, with a concomitante increase in SFA levels.

\section{References}

Buccioni, A., Antongiovanni, M., Mele, M., Gualtieri, M., Minieri, S., \& Rapaccini, S. (2009). Effect of oleic and conjugated linoleic acid in the diet of broiler chickens on the live growth performances, carcass traits and meat fatty acid profile. Italian Journal of Animal Science, 8, 603-614. https://doi.org/10.4081/ ijas.2009.603

Carta, G., Angioni, E., Murru, E., Melis, M. P., Spda, S., \& Banni, S. (2002). Modulation of lipid metabolism and vitamin A by conjugated linoleic acid. Prostaglandins, Leukotrienes and Essential Fatty Acids, 67, 187-191. https://doi.org/10.1054/plef.2002.0417

Chen, S. C., Lin, Y. H., Huang, H. P., Hsu, W. L., Houng, J. Y., \& Huang, C. K. (2012). Effect of conjugated linoleic acid supplementation on weight loss and body fat composition in a Chinese population. Nutrition, 28, 559-565. https://doi.org/10.1016/j.nut.2011.09.008

Choi, J. S., Jung, M. H., Park, H. S., \& Song, J. (2004). Effect of conjugated linoleic acid isomers on insulin resistance and mRNA levels of genes regulating energy metabolism in high-fat-fed rats. Nutrition, 20, 1008-1017. http://doi.org/10.1016/j.nut.2004.08.009

Christie, W. W. (1989). The analysis of fatty acids. Gas Chromatography and Lipids A Practical Guide (pp. 64-84).

da Silva, R. C., \& Gioielli, L. A. (2006). Propriedades físicas de lipídios estruturados obtidos a partir de banha e óleo de soja. Brazilian Journal of Pharmaceutical Sciences, 42, 226-233. https://doi.org/10.1590/ S1516-93322006000200007

Duarte, F., Lara, L., Baião, N., \& Cançado, S. (2010). Efeito da inclusão de diferentes fontes lipídicas em dietas para frangos de corte sobre o desempenho, rendimento e composição da carcaça. Arquivos Brasileiros de Medicina Veterinária e Zootecnia, 62, 439-444. https://doi.org/10.1590/S0102-09352010000200025

Fats, F. A. O. (2010). Fatty acids in human nutrition. Report of an expert consultation. FAO Food and Nutrition Paper, 91, 1-166. Retrieved from http://www.who.int/nutrition/publications/nutrientrequirements/fatsand fattyacids_humannutrition/en

Gouvêa, M. M., Franco, C. F., Marques, F. F., \& Pereira Netto, A. D. (2012). Ácidos Linoleicos Conjugados (ALC)-Os Benefícios que Exercem sobre a Saúde Humana e as Principais Metodologias Analíticas Aplicadas para a sua Determinação em Leites. Revista Virtual de Química, 4, 653-669. Retrieved from http://rvq.sbq.org.br

Halle, I., Jahreis, G., Henning, M., Köhler, P., \& Dänicke, S. (2012). Effects of dietary conjugated linoleic acid on the growth performance of chickens and ducks for fattening and fatty acid composition of breast meat. Journal für Verbraucherschutz und Lebensmittelsicherheit, 7, 3-9. https://doi.org/10.1007/s00003-0110749-5 
Hara, A., \& Radin, N. S. (1978). Lipid extraction of tissues with a low-toxicity solvent. Analytical Biochemistry, 90, 420-426. https://doi.org/10.1016/0003-2697(78)90046-5

Hargrave, K. M., Meyer, B. J., Changlong, L., Michael, J. A., Clifton, A. B., \& Jess, L. M. (2004). Influence of dietary conjugated linoleic acid and fat source on body fat and apoptosis in mice. Obesity Research, 12, 1435-1444. http://doi.org/10.1038/oby.2004.180

Javadi, M., Geelen, M. J., Everts, H., Hovenier, R., Javadi, S., Kappert, H., \& Beynen, A. C. (2007). Effect of dietary conjugated linoleic acid on body composition and energy balance in broiler chickens. British Journal of Nutrition, 98, 1152-1158. http://doi.org/ 10.1017/S0007114507772677

Kang, K., Liu, W., Albright, K. J., Park, Y., \& Pariza, M. W. (2003). Trans-10, cis-12 CLA inhibits differentiation of 3T3-L1 adipocytes and decreases PPAR $\gamma$ expression. Biochemical and Biophysical Research Communications, 303, 795-799. https://doi.org/10.1016/S0006-291X(03)00413-3

Kennedy, A., Martinez, K., Schmidt, S., Mandrup, S., LaPoint, K., \& McIntosh, M. (2010). Antiobesity mechanisms of action of conjugated linoleic acid. The Journal of Nutritional Biochemistry, 21, 171-179. https://doi.org/10.1016/j.jnutbio.2009.08.003

Lavillonniere, F., Chajès, V., Martin, J. C., Sébédio, J. L., Lhuillery, C., \& Bougnoux, P. (2003). Dietary Purified cis-9, trans-11 Conjugated Linoleic Acid Isomer Has Anticarcinogenic Properties in Chemically Induced MammaryTumors in Rats. Nutrition and Cancer, 45, 190-194. http://doi.org/10.1207/S15327914 NC4502_08

Martorell, P., Llopis, S., González, N., Montón, F., Ortiz, P., Genovés, S., \& Ramón, D. (2012). Caenorhabditis elegans as a model to study the effectiveness and metabolic targets of dietary supplements used for obesity treatment: The specific case of a conjugated linoleic acid mixture (Tonalin). Journal of Agricultural and Food Chemistry, 60, 11071-11079. http://doi.org/10.1021/jf3031138

Miranda, J., Lasa, A., Fernández-Quintela, A., García-Marzo, C., Ayo, J., Dentin, R., \& Portillo, M. P. (2011). cis-9, trans-11, cis-15 and cis-9, trans-13, cis-15 CLNA mixture activates PPAR $\alpha$ in HEK293 and reduces triacylglycerols in 3T3-L1 cells. Lipids, 46, 1005-1012. http://doi.org/10.1007/s11745-011-3615-4

Moraes, M., Ribeiro, A., Santin, E., \& Klasing, K. (2015). Effects of conjugated linoleic acid and lutein on the growth performance and immune response of broiler chickens. Poultry Science, 95(2), 237-246. https://doi.org/10.3382/ps/pev325

Pariza, M. W., \& Hargraves, W. A. (1985). A beef-derived mutagenesis modulator inhibits initiation of mouse epidermal tumors by 7,12-dimethylbenz [a] anthracene. Carcinogenesis: Integrative Cancer Research, 6, 591-593. https://doi.org/10.1093/carcin/6.4.591

Pariza, M. W., Park, Y., \& Cook, M. E. (2001). The biologically active isomers of conjugated linoleic acid. Progress in Lipid Research, 40, 283-298. https://doi.org/10.1016/S0163-7827(01)00008-X

Park, Y., Albright, K. J., Liu, W., Storkson, J. M., Cook, M. E., \& Pariza, M. W. (1997). Effect of conjugated linoleic acid on body composition in mice. Lipids, 32, 853-858. http://doi.org/10.1007/s11745-9970109-X

Park, Y., Storkson, J. M., Albright, K. J., Liu, W., \& Pariza, M. W. (1999). Evidence that the trans-10, cis-12 isomer of conjugated linoleic acid induces body composition changes in mice. Lipids, 34, $235-241$. http://doi.org/10.1007/s11745-999-0358-8

Sakomura, N. K., Longo, F. A., Rabello, C. B., Watanabe, K., Pelícia, K., \& Freitas, E. R. (2004). Efeito do nível de energia metabolizável da dieta no desempenho e metabolismo energético de frangos de corte. Revista Brasileira de Zootecnia, 33(6), 1758-1767. https://doi.org/10.1590/S1516-35982004000700014

Santos, R. D., Gagliardi, A. C. M., Xavier, H. T., Magnoni, C. D., Cassani, R., Lottenberg, A. M. P., ... Ramos S. (2013). I Diretriz sobre o consumo de Gorduras e Saúde Cardiovascular. Arquivos Brasileiros de Cardiologia, 100, 1-40. https://doi.org/10.1590/S0066-782X2013000900001

Sarraf, P., Mueller, E., Smith, W. M., Wright, H. M., Kum, J. B., Aaltonen, L. A., ... Eng, C. (1999). Loss-of-function mutations in PPAR $\gamma$ associated with human colon cancer. Molecular Cell, 3, $799-804$. https://doi.org/10.1016/S1097-2765(01)80012-5

Simopoulos, A. P. (2004). Omega-6/omega-3 essential fatty acid ratio and chronic diseases. Food Reviews International, 20, 77-90. https://doi.org/10.1081/FRI-120028831 
Sirri, F., Tallarico, N., Meluzzi, A., \& Franchini, A. (2003). Fatty acid composition and productive traits of broiler fed diets containing conjugated linoleic acid. Poultry Science, 82, 1356-1361. https://doi.org/ $10.1093 / \mathrm{ps} / 82.8 .1356$

Storkson, J. M., Park, Y., Cook, M. E., \& Pariza, M. W. (2005). Effects of trans-10, cis-12 conjugated linoleic acid and cognates on apolipoprotein B secretion in HepG2 cells. Nutrition Research, 25, 387-399. https://doi.org/10.1016/j.nutres.2004.12.008

Suksombat, W., Boonmee, T., \& Lounglawan, P. (2007). Effects of various levels of conjugated linoleic acid supplementation on fatty acid content and carcass composition of broilers. Poultry Science, 86, 318-324. https://doi.org/10.1093/ps/86.2.318

Szymczyk, B., Pisulewski, P. M., Szczurek, W., \& Hanczakowski, P. (2001). Effects of conjugated linoleic acid on growth performance, feed conversion efficiency, and subsequent carcass quality in broiler chickens. British Journal of Nutrition, 85,465-473. http://doi.org/10.1079/BJN2000293

Tontonoz, P., \& Spiegelman, B. M. (2008). Fat and beyond: the diverse biology of PPAR $\gamma$. Annu. Rev. Biochem., 77, 289-312. http://doi.org/10.1146/annurev.biochem.77.061307.091829

Wang, Y., \& Jones, P. J. (2004). Conjugated linoleic acid and obesity control: efficacy and mechanisms. International Journal of Obesity, 28, 941-955. http://doi.org/10.1038/sj.ijo.0802641

West, D. B., Delany, J. P., Camet, P. M., Blohm, F., Truett, A. A., \& Scimeca, J. (1998). Effects of conjugated linoleic acid on body fat and energy metabolism in the mouse. American Journal of Physiology-Regulatory, Integrative and Comparative Physiology, 275, R667-R672. Retrieved from http://ajpregu.physiology.org/ content/275/3/R667.full.pdf + html

Yuan, G., Chen, X., \& Li, D. (2015). Modulation of peroxisome proliferator-activated receptor gamma (PPAR $\gamma$ ) by conjugated fatty acid in obesity and inflammatory bowel disease. Journal of Agricultural and Food Chemistry, 63, 1883-1895. http://doi.org/10.1021/jf505050c

Zhang, G. M., Wen, J., Chen, J. L., Zhao, G. P., Zheng, M. Q., \& Li, M. W. (2007). Effect of conjugated linoleic acid on growth performances, carcase composition, plasma lipoprotein lipase activity and meat traits of chickens. British Poultry Science, 48, 217-223. https://doi.org/10.1080/00071660701255841

Zhang, H., Guo, Y., Tian, Y., \& Yuan, J. (2008). Dietary conjugated linoleic acid improves antioxidant capacity in broiler chicks. British Poultry Science, 49, 213-221. https://doi.org/10.1080/00071660801989836

Zhou, X.-R., Sun, C.-H., Liu, J.-R., \& Zhao, D. (2008). Dietary conjugated linoleic acid increases PPAR $\gamma$ gene expression in adipose tissue of obese rat, and improves insulin resistance. Growth Hormone \& IGF Research, 18, 361-368. https://doi.org/10.1016/j.ghir.2008.01.001

\section{Copyrights}

Copyright for this article is retained by the author(s), with first publication rights granted to the journal.

This is an open-access article distributed under the terms and conditions of the Creative Commons Attribution license (http://creativecommons.org/licenses/by/4.0/). 